\title{
ERRATUM
}

\section{Erratum to: Current status of tissue culture and genetic transformation research in cotton (Gossypium spp.)}

Vijaya Naresh Juturu • Gopala Krishna Mekala •

Giridara Kumar Surabhi · P. B. Kirti

Published online: 29 January 2015

(C) Springer Science+Business Media Dordrecht 2015

\section{Erratum to: Plant Cell Tiss Organ Cult}

\section{DOI 10.1007/s11240-014-0640-z}

The list of authors in the original publication was incomplete. It should have included author Giridara Kumar Surabhi, as listed in this erratum.

The online version of the original article can be found under doi:10. 1007/s11240-014-0640-z.

V. N. Juturu · G. K. Mekala · G. K. Surabhi

Plant Molecular Biology Laboratory, Agri Biotech Foundation

(Formerly AP Netherlands Biotechnology Programme),

Hyderabad 500030, India

Present Address:

G. K. Surabhi

Regional Plant Resource Centre, Bhubaneswar, Orissa, India

P. B. Kirti $(\bowtie)$

Department of Plant Sciences, School of Life Sciences,

University of Hyderabad, Hyderabad 500046, India

e-mail: pbkirti@yahoo.com; pbksl@uohyd.ernet.in 